\title{
Conscientia duce, comite scientia $\left.{ }^{(}\right)$
}

\section{Benedicto de Siqueira Ferreira}

Cronos, o inexorável Deus do Tempo, entretece nossas vidas do nada.

"Vivemos de lembranças e de ambições, entre a saudade e a esperança. $O$ presente não existe. Este mesmo instante já não é nosso - como disse o Poeta - fugiu, dissipou-se, desapareceu na treva do desconhecido e no grande silencio que a tudo e a todos há de devorar. 0 hoje é uma ilusão; o que chamamos agóra é uma vaga mistura de recordações e de desejos, um pouco do prazer e do pesar que já tivemos e um pouco da felicidade e do desgosto que advinhamos. Já tenho saudades de vós, de vossa companhia e desta noite tão cheia de encantamentos, já estou prelibando os minutos que daqui a pouco viverei, embalado pela evocação de vossas fisionomias", dos tres anos de estudo e de amizade que entrelaçaram nossas vidas para sempre, desta festa pagã em sua contextura mas com profundos laivos de religiosidade em sua essência, desta cerimonia em que sois sagrados sacerdotes da justiça, de vossa generosidade que, superlativa me esmaga, mas que alçando-me muito acima de meus apoucados méritos de obscuro professor, para aqui me traz e me exalça pela palavra amiga de vosso brilhante orador, fruto de vosso amor à Academia que neste momento de Adeus eu represento.

Tudo isto já se acha em meu coração porque é passado! Porque Cronos, o impiedoso Deus do Tempo já transformou

(*) Discurso de paraninfo aos bacharelandos de 1947. 
em Saudade o que era presente.. porque Cronos, o misterioso filho de Urano - fez do nada que é o presente, o tudo que é o passado e o porvir.

Que resta na verdade de nós?

A consciência do que somos, a ciência que adquirimos, a incerteza e a esperança no futuro.

"Conscientia duce, comite scientia".

Com a consciência por guia, a ciência por companheira, daqui partís para a conquista do Porvir.

Armas para as lutas de amanhã, arnezes contra as asperezas da vida, talismãs contra o Destino, este extranho filho da Noite e do Cáos!

$E$ vós, snrs. bacharelandos, escolhestes carreira das mais brilhantes mas tambem das mais arduas.

Sereis vós que ireis integrar todo um destes três supremos poderes do Estado, o Poder Judiciário, o que mais alto se alevanta sobre a face da terra pois "nada mais aproxima o homem de Deus que julgar seu semelhante".

$\mathrm{Na}$ majestade da toga, na singeleza e austeridade da beca, sua irmã gêmea, ireis exercer a nobilíssima e dignificadora missão de dar a cada um aquilo que é seu.

Si não quizerdes, porem, seguir esta trilha que leva o jurista a este "Seminarium dignitatum" que é o foro, podeis volver vossas vistas para este outro Poder que Rousseau via como o coração da Pátria!

O Poder Legislativo é o coração do Estado, pontifica o genial sociólogo, o Executivo o cérebro. $O$ cérebro pode entrar em colapso e o individuo viver ainda.. mas logo que o coração cessa de bater, a creatura morre. .

$\mathrm{E}$, como deveis ter percebido, o tecido nobre deste orgão é o jurista, pela adequação do seu preparo, pela especificidade de sua cultura..

Mas, legislando, postulando, julgando, governando, o vosso ideal deve ser sempre servir a Patria que tanto de vós necessita, de vossas energias moças, de vossa sinceridade, de vosso amor aos estudos, de vossa cultura, neste alvorecer da Democracia. 
Mercê de Deus, findo o infindável retorno à Idade Média - novo ciclo se abriu para a Humanidade.

Esta, porém, insatisfeita, mal egressa de regimes que transformaram Pátrias em Senzalas, já reclama: "esta não é a Democracia dos meus sonhos!"

E mesmo vosso orador intérprete se faz deste desanimo, desta descrença nas virtudes da Democracia Brasileira!

E’ bem de ver que a Democracia não é bálsamo para todas as feridas, panacéa para todos os males sociais, muitos dos quais derivam da imperfeição humana; não é remedio cuja eficacia se faça sentir de imediato neste imenso organismo que é o organismo social.

Enaltecendo o papel desempenhado por Ruy Barbosa, como consolidador da República, afirmava em 1930 neste mesmo cenário seu discípulo dileto o senador JoÃo MANGABEIRA:

"Não basta derrubar um trono, com um levante militar, para que da montanha de escombros do império, surja alviçareira a República por entre as baionetas da tropa. Para o primeiro ato bastaria uma espada, acostumada a rebrilhar no sol das batalhas, a lampejar no caminho da vitoria, em rasgos de heroismo, ante os regimentos entusiasmados. Mas para a creação do regimen político não seria suficiente o rótulo com que o nomeassem ou de que o revestissem as proclamações do movimento triunfante!"

Assim tambem não basta que haja ruido uma ditadura para que de seus escombros que na verdade escombros não são pois ditadura é sempre ruina, ressurja a Democracia.

Não basta que se reestruture o país nos moldes democráticos, mistér se faz que a esse corpo organizado se dê uma nobre alma, uma mentalidade democrática!

Mas qual o artífice que irá vivificar esse organismo comunicando-lhe a chama ardente do Ideal?

A voz do jurista, a voz daquele que habituado ao trato das normas que regem a vida social bem sabe que o remédio não é a demagogia mas a sinceridade, não é a discussão 
estéril mas a disciplina férrea do trabalho, não é o aleive reciproco mas o respeito mutuo, não é a ameaça mas o conselho e principalmente a mais impressionante forma deste: o exemplo.

Não ignóra o jurista que alem das normas religiosas, morais e jurídicas o homem se deve tambem subordinar, como pondera Icilio Vanni, às normas de conveniência, de decoro, de tacto nas relações sociais, de cortesia e até de etiqueta e de cerimonial, todas tendentes a facilitar as relações de sociabilidade impondo respeito à individualidade alheia, amparo que são, como diz IHering, da moralidade de um povo.

Mais uma vez pois é de se recordar a apóstrofe de LEvY Ulman: a hora é a do jurista.

Si esta advertência não conseguiu deter a humanidade às bordas do abismo da guerra, certamente indicará a escolha do jurista para a reconstrução do mundo que hoje se opera.

Sim a hora é do jurista ainda mais porque não basta que o regime seja democrático necessário se torna que seja legítimo.

Mas como se aferir esta qualidade?

Confessa Guglielmo Ferrero, em sua notável obra "Pouvoir" que com "Adventure" e "Reconstrutione" integram famosa trilogia que fez editar na América, fugindo às bastilhas européias do século XX, que só aos 47 anos de idade pela leitura das memórias de Talleyrand teve a revelação dos principios da legitimidade do Poder.

Sete páginas de Talleyrand e alguns pensamentos de PASCAL, toda a literatura ocidental sobre a legitimidade do Poder, induziram o ilustre historiador de Roma a investigar o misterio, pois, como confessa, seu desconhecimento do assunto de cuja existência nem siquer suspeitava, nada mais era que uma gota no Oceano da universal ignorância.

Porque perduram longo tempo certos governos, certos regimes, rigidos e altaneiros como o Carvalho Inglês, en- 
quanto outros passam ligeiros como sombras sinão violentos e arrasadores como vendavais?

E' que a legitimidade é a pedra de toque da permanencia no Poder.

Atentai bem para os principios da legitimidade e encontrareis o segredo dos golpes de Estado, das revoluções, das guerras civis, e penetrareis assim nos bastidores secretos da História!

Vejamos rapidamente quais esses principios em uma Democracia.

Advem nesta o Poder do sufrágio universal.

“ $E$ ' entretanto evidente, acentua FerRero, que não há razão alguma para se atribuir ao sufragio universal o dom miraculoso da bôa escolha e que se se disser bruscamente a milhões e milhões de homens e mulheres, habituados a obedecer: "sois soberano, governae", só Deus poderá saber o que irá acontecer..." Deus. . e nós tambem sabemos...

"A soberania do povo é o rebanho conduzindo o pastor, é a piramide invertida apoiada sobre o vertice".

"Soberano o povo? Essa massa enorme e informe de seres dentre os quais grande número apenas atingio uma pre-consciência crepuscular de si mesmo?

Não, não é possível pois este princípio não resiste a menor crítica.

"A maioria de votos nada prova, nem a capacidade de um homem nem a de um partido, nem a verdade de uma doutrina, nem a sabedoria de uma decisão, nem a justiça de um veredictum".

"Um só homem pode ter razão contra o Universo inteiro". Quantos não se sacrificaram em holocausto as suas idéias avançadas em demasia para o século em que viveram?

O princípio hereditário tambem nenhum valor tem em si pois a genealogia de nada pode ser fiadora.

Como se explica então que hoje bem aceita seja a eleição pelo povo como principio legitimador do Poder, como 
o éra o princípio da hereditariedade até os fins do seculo XVIII?

E' que por consenso unanime dos povos civilizados tal se acha aceito e é nesse sentido e tão só que se pode falar em contrato social, "o famoso mito creado por Rousseau".

Si se perguntasse a um cidadão de Veneza porque governava o sereníssimo dodge a resposta sería que êle havia sido escolhido pelo "Consiglio Maggiore" de que eram membros por direito de herança todos os varões das 450 famílias nobres inscritas no Livro de Ouro da aristocrática República.

Entre nós a resposta será que a eleição pelo povo legitíma a ascenção ao Poder.

Mas porque si a maioria não tem o dom maravilhoso da escolha acertada?

$\mathrm{O}$ único fundamento que FerRero encontra é o desejo do homem de se livrar do temor que é inato em seu coração, como reflexo do instinto de conservação.

Todos os animais, todas as creaturas, afirma, vivem em estado de perpétuo temor de perigos reais e de perigos imaginários.

De todos os animais creados, é entretanto o homem o único que medroso por natureza, orgulhosamente consegue reprimir seus instintos pela coragem que sua dignidade lhe impõe.

Animal de índole gregária para vencer o seu temor, o temor misterioso e recíproco entre os que enfeixam em suas mãos o Poder e os governados, procura crear formulas de exorcismo que são os principios de legitimidade daquele.

Aprimorando sua cultura verifica afinal que os que melhor se coadunam com a dignidade humana, melhor respeitam os direitos impostergaveis do homem são os que integram a Democracia.

Quando estes principios faltam, podeis verificar que o temor reciproco volta a imperar na sociedade, o Pavor dos liranos advindo da consciência do principio violado, pavor que é a fonte donde derivam a violencia, a opressão, a des- 
truição das instituições liberais, o aniquilamento das forças vivas da Nação que por tantas vezes a Historia registra e que nós tão bem conhecemos!

$\mathrm{E}^{\prime}$ que o usurpador tem consciencia da revolta latente dos oprimidos.

Desde que uma das partes não o respeita, o principio da legitimidade perde sua força e não oferece mais segurança nem ao Poder nem aos Governados: a confiança desaparece, o temor reciproco surge, a violencia se instaura...

E' pois necessário não só que o Poder advenha legitimamente como desta mesma maneỉra seja exercido mercê de certas precauções que realmente são outros tantos principios de sua legitimidade.

Aceita a eleição como principio básico, é necessário que não seja ela uma fraude, que não seja contaminada pela violencia e pela má fé. E' este um imperativo categórico da legitimidade do poder que exerce o Eleito. O desrespeito a esta regra explica a queda de muito governo aparentemento eleito mas que na realidade nada mais representava que uma minoria disfarçada em maioria.

Si a unanimidade fosse cousa comum estaria com a eleição resolvido o problema, mas é circunstancia rara como sabeis, planta que ao que parece, só medra em clima glacial como o da Russia e não se aclimata em paises tropicais como o nosso...

Maioria e minoria, eis o que surge quasi que fatalmente, como o resultado de um pleito honesto.

Quais porem devem ser suas relações reciprocas e com a vontade soberana do povo?

Este é o problema crucial das Democracias.

E' necessário que estas duas esferas reciprocamente inviolaveis se completem, se juxtaponham sob pena de se violar, de se mutilar a vontade soberana do Povo, fonte da legitimidade do Poder. 
A oposição é orgão tão vital em uma Democracia como o Governo.

Mas como conciliá-los ?Poder e oposição importam dualismo e dualidade equivale sempre a luta, degenera frequentemente em odio e na necessidade de destruição reciproca.

As tentações são imensas...

Si o Governo fôr minoria disfarçada em maioria valerse-á do Poder para aniquilar a maioria que teme. A conse quência será fatalmente funesta.

Mas ainda que os que detem o Poder sejam representantes da maioria, devem reconhecer que a oposição pode se transformar em maioria, que são pois instaveis no Poder e jamais se prevalecer deste para nele se eternisar, pela violencia e pela fraude.

Por outro lado, quanto à minoria só se legitima seu direito de oposição quando respeita lealmente o direito da maioria de governar.

O direito de criticar, adverte Ferrero, pode ser exercido com tal aspereza, tamanha injustiça e tão manifesta má fé que pode paralizar o poder e comprometer sua legitimidade tanto quanto as manipulações e fraudes eleitorais da maioria.

Lealdade e cordialidade entre os adversários eis o que preconiza o sociólogo pois nada é mais perigoso para uma Democracia, nada a enfraquece tanto como pequenos grupos exasperados por odios irreprimiveis a lutarem, esquecidos da causa pública, alimentando paixões corrosivas que não podem levar senão a uma sublevação total da ordem.

Só pelo respeito mutuo podem esses dois orgãos indispensaveis ao florescimento da Democracia, unifitcar seu dualismo, polarisando assim a vontade geral da Nação.

A obediencia a esta regra tem ainda a virtude de conseguir mais forte adesão do povo às instituições democráticas, com o que atingirá sua plenitude o principio da legitimidade do regime. 
Si examinardes, Snrs. bacharelandos os princípios que vêm de ser resumidamente expostos, num rápido apanhado do monumental trabalho de Ferrero, verificareĩs que assentam todos na lealdade, na sinceridade, naquilo que os ingleses denominam "fair play", manifestações dessa luz interior que ilumina nossa alma e que é a Consciencia, nosso juiz e nosso algoz!

"Prima est haec ultio, quod se Judice nemo nocens absolvitur".

Eis porque a Conciencia deve ser vosso guia qualquer que seja a atividade a que vos entregueis como jurista.

Conscientia duce!

Mas não basta.

Mistér se faz que tenhais a ciencia por companheira Comite scientia - pois só assim jamais ireis encarnar a figura grotesca do homem panacéa, do homem panacéa que tão maravilhosamente descreve RuY em sua vibrante e inolvidável "Oração aos Moços".

"Haveis de conhecer, é o mestre quem o diz, como eu conheço paises onde quanto menos ciencia se apurar, mais sabios florescem. Há, sim, dessas regiões, por este mundo alem. Um homem (nessas terras de promissão) que nunca se mostrou lido ou sabido em cousa alguma, tido e havido é por corrente e moente no que quér que seja; porque assim o aclamam as trombetas da política, do elogio mutuo ou dos corrilhos pessoais e o povo subscreve a nescia atoarda.

"Financeiro, administrador, estadista, chefe de Estado, ou outro qualquer lugar de ingente situação e assustadoras responsabilidades, é, a pedir de boca, o que se diz mão do pronto desempenho, formula a quaisquer dificuldades, chave de todos os enigmas".

"Tenham por averiguado que, onde quer que o colocarem, dará conta o sujeito das mais arduas empresas e solução dos mais emaranhados problemas. Se em nada se aparelhou, está em tudo e para tudo emparelhado. Ninguem vos saberá informar porque. Mas todo mundo vo-lo dará 
por liquido e certo. Não aprendeu nada, e sabe tudo. Ler, não leu. Escrever, não escreveu. Ruminar, não ruminou. Produzir, não produziu. E' um improviso omnisciente, o fenomeno de que poetava Dante:

"In picciol tempo gran dottor si feo".

"A esses homens panacéas, a esses empreiteiros de todas empreitadas, a esses aviadores de todas as encomendas, se escancelam os portões da fama, do poderio, da grandeza e, não contentes de lhes aplaudir entre os da terra a nulidade, quando Deus quer, a mandam expor à admiração do estrangeiro".

Mas notai o contraste e escolhei. E' ainda a voz imperecivel do Mestre que se vai ouvir:

"Estudante sou. Nada mais. Mau sabedor, fraco jurista, mesquinho advogado, pouco mais sei do que saber estudar, saber como se estuda e saber que tenho estudado. Nem isso mesmo sei, si saberei bem".

Diante do Confiteor do Mestre, snrs. bacharelandos, só nos resta, a nós mortais filhos de Themis, curvamos a fronte e prosseguindo na oração nos penitenciarmos das madrugadas e manhãs de estudo que não sacrificamos no altar da Patria, como a consciência ordena ao levita do Direito.

Este na verdade é o paradoxal anatema que pesa sobre o jurista: para chegar a mestre deve ser o eterno discípulo!

Estudar foi o que fizemos juntos ao pé das Arcadas e na verdade vos digo que eu não sei mesmo se siquér isto bem vos ensinei, mau estudante que sou!

Orgulho é porem do Mestre que o Discipulo o ultrapasse pois na glória deste se revê.

$\mathrm{E}$, eu de vós me orgulho, snrs. bachareis de 1947 porque sois a geração que madrugou nas lutas pela liberdade, nos combates pela Democracia.

Mal havieis ingressado na velha Faculdade de Direito de São Paulo, e logo no primeiro ano, calouros timidos 
ainda, ali mesmo no Largo de São Francisco recebestes, com vossos, com nossos colegas que daqui já partiram vosso batismo de fogo, em 9 de Novembro de 1943, avançando assim agigantado passo na gloriosa jornada da libertação da Pátria.

Pertenceis à geração dos que integraram no mundo a falange heroica que aniquilou regimes totalitários, expressões da força bruta e de peremptoria negação do direito.

Com este passado como patrimonio podeis partir como depositários da nossa confiança.

Si soubestes lutar pela Democracia, evidentemente sabereis defende-la, mórmente agora que ela ensaia seus primeiros passos.

Não duvideis jamais das suas virtudes si aqui ou acolá, como consequencia da imperfeição humana, nâo corresponder o cenário politico de nossa Patria aos vossos ideais.

De início, isto frequentemente ocorrerá pois o povo afastado criminosamente por largos anos da gestão da cousa pública terá que aprender de novo a ser cidadão.

Si alguem em momento de desanimo ou de desespero se mostrar saudoso da aparente ordem e disciplina que reinava nos paises governados pela força, lembrai-lhe que ninguem jamais aprendeu a ser livre acorrentado em uma senzala.

A alegria da libertação poderá quando se rompem as barreiras da opressão conduzir a excessos que toquem as raias da licenciosidade, mas só usufruindo a liberdade é que se aprende a respeitá-la.

Democracia é cultura e escola de civismo. .

Hoje a imprensa é livre e livre é a tribuna... e a voz do jurista que não se conturba com a fereza das paixões saberá se elevar acima destas, transpondo os humbrais da Academia, onde sempre se fez ouvir, lembrando que a liberdade só é possivel sob a égide do Direito e da Justiça! 